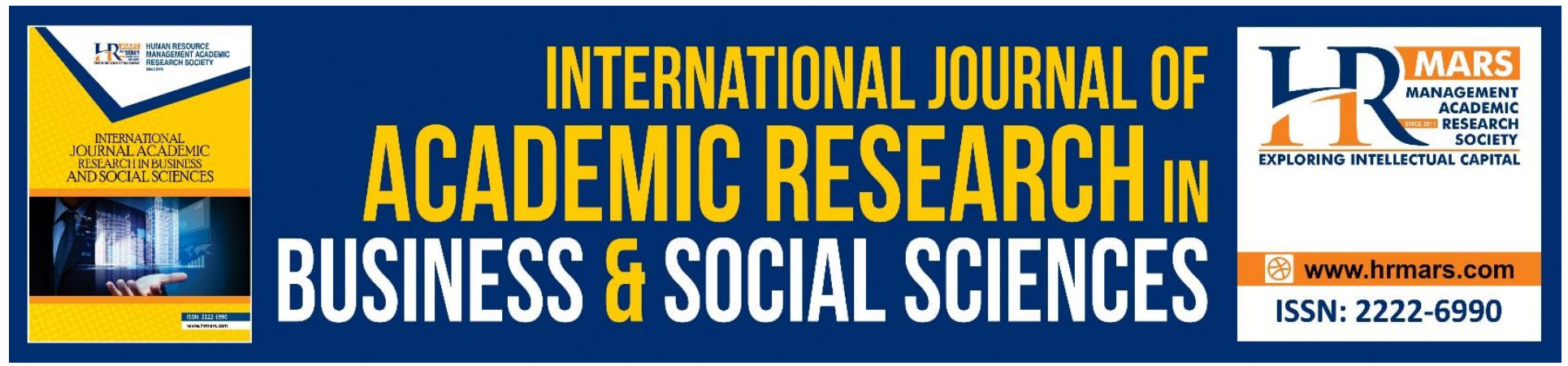

\title{
Predictor Factors for Collective Leadership: A Case of Secondary Schools
}

Shiveh Sivalingam, Suhaida Abdul Kadir, Navaratnam Vejaratnam, Soaib Asimiran

To Link this Article: http://dx.doi.org/10.6007/IJARBSS/v8-i12/5006 DOI: $10.6007 /$ IJARBSS/v8-i12/5006

Received: 03 Nov 2018, Revised: 21 Nov 2018, Accepted: 06 Dec 2018

Published Online: 18 Dec 2018

In-Text Citation: (Sivalingam, Kadir, Vejaratnam, \& Asimiran, 2018)

To Cite this Article: Sivalingam, S., Kadir, S. A., Vejaratnam, N., \& Asimiran, S. (2018). Predictor Factors for Collective Leadership: A Case of Secondary Schools. International Journal of Academic Research in Business and Social Sciences, 8(12), 198-209.

\section{Copyright: (C) 2018 The Author(s)}

Published by Human Resource Management Academic Research Society (www.hrmars.com)

This article is published under the Creative Commons Attribution (CC BY 4.0) license. Anyone may reproduce, distribute, translate and create derivative works of this article (for both commercial and non-commercial purposes), subject to full attribution to the original publication and authors. The full terms of this license may be seen

at: http://creativecommons.org/licences/by/4.0/legalcode

Vol. 8, No. 12, 2018, Pg. 198 - 209

Full Terms \& Conditions of access and use can be found at http://hrmars.com/index.php/pages/detail/publication-ethics 


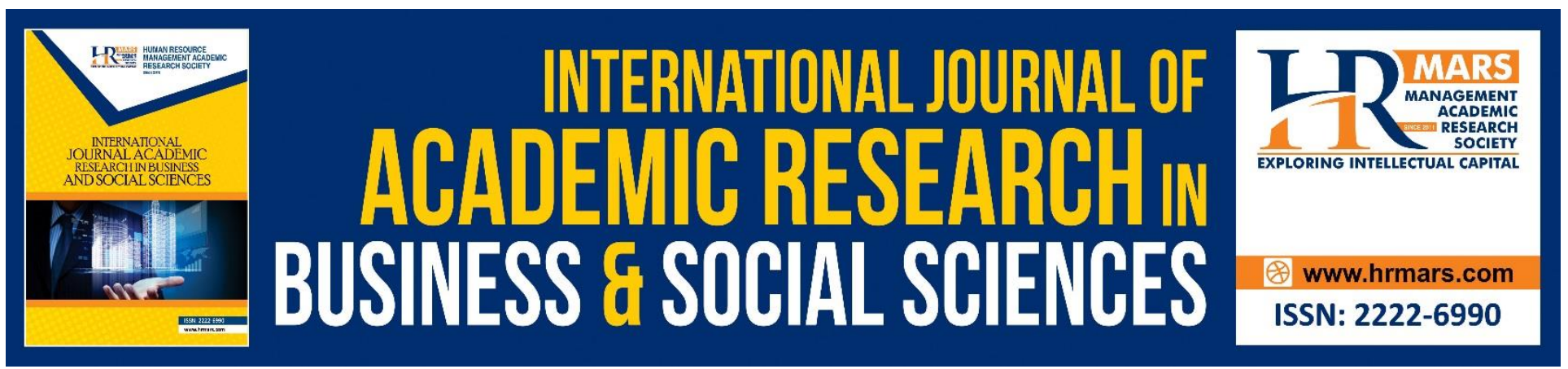

\title{
Predictor Factors for Collective Leadership: A Case of Secondary Schools
}

\author{
Shiveh Sivalingam, Suhaida Abdul Kadir, Navaratnam Vejaratnam, \\ Soaib Asimiran
}

Faculty of Educational Studies, Universiti Putra Malaysia, 43400 UPM Serdang, Selangor Darul

Ehsan, Malaysia

\begin{abstract}
The purpose of this paper was to study the factors predicting collective leadership in Malaysian secondary schools in Kuala Lumpur. The survey method is used to measure the variables, which influences collective leadership practices among 402 respondents from 103 government secondary schools in Kuala Lumpur. The findings utilized the inferential analysis - regression. The results show that school culture and sources of leadership efficacy are predictors for collective leadership. This Study focused on teachers from secondary government schools therefore results of this study cannot be projected liberally. The findings of the study supports the social exchange theory, which explains the relationship between the variables, studied. In addition, the findings of the research collaborate with Bandura's (1986) theory with leadership elements. This paper introduces a new paradigm in research into sources of leadership efficacy and the concept of collective leadership.
\end{abstract}

Keywords: Collective Leadership, Source Of Leadership Efficacy, School Culture, Secondary School Teachers

\section{Introduction}

A relatively narrow but fundamental perspective on leadership because its focus is on combined effects for all stakeholders (Leithwood \& Louis, 2012) - is how collective leadership is aptly described as it slowly gains popularity in educational institutions today. It is not about just the leader being a leader but it is about a leader who can distribute leadership to subordinates without losing the element of the overall leadership and garnering the dynamism of teamwork. Thus far, most research on collective leadership is focused in the context outside Asia and its development in this region is fairly recent. Rahimah and Ghavifekr (2014) in their research, found that currently, leadership is about vitality, flexibility, innovativeness, sharing of power and authority and intensifying the leadership capacity of all stakeholders. This is clearly in line with Malaysian Education Blueprint 20132025, which encourages teamwork, thus paving the way for collective leadership, which can enhance teamwork effectively. Rabindarang, Khuan and Khoo (2015) in their study emphasized that good 
relationships among leaders and workers give a positive impact for the organization's effectiveness. Rosnarizah and Hussein (2015) quotes Harris (2002) who stated, trends in educational leadership now no longer see the principal shoulder all responsibilities (as) it is more focused on how to create a culture of accountability and learning as well developing school leadership capabilities. This is in support of research carried out by Rosnarizah and Zulkifli (2009), which found that collaborative styled leadership, prevailed in high schools in Malaysia. Thus, collective leadership creates a collectivistic belief about capability among its followers.

The first pertinent determinant to collective leadership involves the variable of sources of leadership efficacy. According to Bandura (1997), through his social cognitive theory, efficacy is the perception of teachers in a school; that the efforts of the faculty as a whole will have a positive effect on the organization. This belief is embedded in Bandura's (1997) social cognitive theory, which carries the idea that cognitive processes mediate change but that cognitive events are induced and altered most readily by experience of mastery arising from effective performance. This enables the idea of sources of leadership efficacy which is a specific form of efficacy corresponding with the level of confidence in the knowledge, skills and abilities associated with leading others (Hannah et. al., 2008).

The significance and prominence of sources leadership efficacy in the field of leadership have prompted researchers to extend their investigation into the four elements, which are performance accomplishment, vicarious experience, social persuasion and emotional arousal. Sources of leadership efficacy in teachers is pivotal in the exercise of leadership in schools. Efficacious teachers review their experiences more adaptively, plan and organize more effectively and are more resilient when faced by obstacles compared with teachers with lower sources of leadership efficacy (Tschannen-Moran et.al., 1998; Woolfolk Hoy \& Davies, 2006). Sources of leadership efficacy have been found to predict the effort teachers put forward, how efficiently they stand tenacious in facing challenges, how well teachers monitor and motivate themselves to attain what they achieve and what options they choose in life; and all these point to the reasons why researchers study how efficacy influences the motivation and behaviour of individuals in an academic setting (Pjares, 2002).

The attainment of optimum collective leadership skills and sources of leadership efficacy can only be engineered through a positive school culture. The elements of leadership, efficacy and school culture must work together for improved leadership performance. Researchers have highlighted that these elements have a compounding effect on school. The 'Global Leadership and Organizational Behaviour Effectiveness' (GLOBE) report underlined that school culture influences leadership and that culture takes the place of primacy in work on leadership (House \& Javidan, 2004). Further, scholars have also noted that effective school leadership is contingent on a thorough understanding of school culture (Leithwood \& Jantzi, 2008; Peterson \& Deal, 2002; Fullan, 2001; Sergiovanni, 2000; Deal \& Peterson, 1999). The relationship between school culture and efficacy is also found to have compounding effects of positively influencing leadership (McLeod, 2012).

School culture is defined as the system of basic assumptions, norms and values as well as the cultural artefacts which are shared by school members and influence their functioning at school (Bolman \& 
Deal, 2013; Maslowski, 2006; Van Houtte, 2005; Cox, 1993). Jerald (2006) assumed an easier understanding; to mean the relationship between the administration and the teachers, teachers and teachers, teachers and students and students and students, in addition to the school's interaction with the community and other stakeholders. How things are attained in an organization sets the order for the culture of a school, hence it facilitates or inhibits the development of teachers in a professional learning organization (Chapman \& Gregory, 2013).

\section{Statement of Problem}

Leadership is the foundation to excellent management in any institution. Teachers and the administration play equal roles to manifest the leadership roles they take on, creating an ideal situation in educational institutions. However, the actual situation in educational institutions is one where teachers find difficulty to ascertain domains that are core to leadership. In addition, leadership is dismissed for yet another label of ongoing staff development. Also, in some cases, leadership capability in teachers is undermined, for insecurity issues present within the administration. Thus, studying the aspect of sources of leadership efficacy and analyzing school culture and its dominant effect on collective leadership in Kuala Lumpur secondary schools will enhance knowledge into the pertinence of having these aspects as leaders amongst the teaching fraternity.

Previous studies usually lay focus on other types of leadership but presently, the idea of leadership that is gaining momentum is collective leadership. Ni et.al. (2017) report in their research that knowledge on collective leadership is very limited.

There is also a lack of studies on collective leadership involving teachers in Malaysia. This is why this study sets out to discover the status of collective leadership and its correlation with sources of leadership efficacy and school culture.

\section{Objectives of this Study}

The research objective is to determine factors predicting collective leadership among secondary school teachers.

\section{Methodology and Data Analysis}

This study utilizes the survey method. The target population for this study is secondary government school teachers while the accessible population would be secondary school teachers in chosen locations, by zone, in Kuala Lumpur. A total of 402 secondary school teachers participated in this study. To determine the population for this study, several past studies were referred to. In the study of Kuala Lumpur teachers carried out by lyer (2008), collegiality and cooperation were the third and fourth choices reflected in the perception of teamwork as a reflection of efficacy in effective schools. This study and a few others more, stirred an interest to study the contribution of sources of efficacy in leadership among the teachers within Kuala Lumpur schools. Since the population of teachers for this study is spread across Kuala Lumpur, a random cluster sampling method was used to select the samples for this particular study. This study was carried out among 103 government secondary schools in Kuala Lumpur. The schools selected were spread across three zones, namely Bangsar/Pudu, 
Keramat and Sentul.

The collective leadership instrument used in this study derived from Education leadership a survey designed by Leithwood (2012), which consists of 13-items. Meanwhile, sources of leadership efficacy was measured using a 13-item survey that was adapted from Usher (2006) who designed the original instrument based on Bandura (1997). Finally school culture was measured using a 24-item survey that was designed by Gruenert \& Valentine (1998). The constructs were later translated to Bahasa Melayu for better understanding of the subjects and were measured using the 5-point Likert scale. All items for the survey, used scales ranging from (1) Strongly Disagree (2) Disagree (3) Moderately Disagree (4) Agree (5) Strongly Agree. All three instruments were consolidated into a formal questionnaire and reviewed by the local experts as a process of instrument content validation. The pilot test was carried out in all three districts of Kuala Lumpur - Bangsar/Pudu, Keramat and Sentul, as per the actual study. A total of 30 teachers were randomly selected, 10 from each district, for the pilot test. Below are the results of the pilot test and actual study, presented in Table 1 . With reference to Table 1, the Cronbach Alpha reading for each instrument was more than 0.7 for the pilot test and the actual study. Given that the reliability scales are supported sufficiently, the statistical analysis could be conducted with conviction (George \& Mallery, 2003).

Table 1: Reliability Analysis of the Instrument (Alpha Coefficient) for the Actual and Pilot Study

\begin{tabular}{lllll}
\hline Section & Instrument & $\begin{array}{l}\text { No. } \\
\text { Items }\end{array}$ & $\begin{array}{l}\text { of } \\
\text { (n = 30) }\end{array}$ & $\begin{array}{l}\text { Actual Study } \\
(\mathrm{n}=402)\end{array}$ \\
\hline B & Collective leadership & 13 & 0.721 & 0.810 \\
C & $\begin{array}{l}\text { Sources of efficacy and collective } \\
\text { leadership }\end{array}$ & 13 & 0.743 & 0.890 \\
D & $\begin{array}{l}\text { School culture and collective } \\
\text { leadership }\end{array}$ & 24 & 0.871 & 0.940 \\
\hline
\end{tabular}

The following section synthesizes the findings of this study.

\section{Research Finding}

\section{Contribution of Sources of Leadership and School Culture Efficacy towards Collective Leadership}

A multiple regression was performed to answer the objective of the research which is to determine the most dominant factor influencing collective leadership among the respondents. From the regression analysis, it is was found that both variables were significantly found to predict collective leadership since the $p$ value for those variables were less than $\alpha$ value 0.05 . Those variables are sources of leadership efficacy and school culture. Since the two variables values are positive, this indicates that there are positive relationships between the variables and outcome.

The R2 obtained was 0.372 which indicates $37.2 \%$ variation in collective leadership which is explained by the independent variables. From this result, it can be concluded that sources of leadership efficacy and school culture contribute $37.2 \%$ towards the collective leadership. 
The regression model fits the data since the ANOVA result shows that $F$ value was large $(F=27.167$, $\mathrm{p}<0.000)$. This shows that the slope for estimate linear regression line was not equal to zero. This confirmed that there was a linear relationship between the predictors and the dependent variables.

Thus, when source of leadership efficacy is exercised in schools, it will increase the level of collaborative leadership in that school. If the effects of all the other variables were held constant, the $b$-value show that Sources of Leadership Efficacy $(\beta=0.332, t=7.250, p<0.05)$ and School Culture $(\beta$ $=0.372, t=8.134, p<0.05$ ) equally contribute in explaining collective leadership. It also can be seen that, if one unit increases in Sources of Leadership Efficacy, it will contribute 0.332 of the unit to collective leadership. Likewise, School Culture will contribute 0.372 of the unit for collective leadership.

Therefore the regression analysis is summarized into the following,

$\hat{\mathbf{Y}}=0.332 \mathrm{x}_{1}+0.372 \mathrm{x}_{2}+1.672$

Table 2: Regression Analysis

Regression Result

Model Summary

\begin{tabular}{lllll}
\hline Model & $\mathrm{R}$ & R Square & Adjusted R Square & $\begin{array}{l}\text { Std. Estimate } \\
\text { Est of the }\end{array}$ \\
\hline 1 & $.610^{\mathrm{a}}$ & .372 & .369 & .303 \\
\hline
\end{tabular}

a. Predictors: (Constant), sources of leadership efficacy, school culture

\section{ANOVA $^{\mathrm{a}}$}

\begin{tabular}{|c|c|c|c|c|c|c|}
\hline Model & & $\begin{array}{l}\text { Sum } \\
\text { Squares }\end{array}$ & of $\mathrm{df}$ & Mean Square & $\mathrm{F}$ & Sig. \\
\hline \multirow[t]{4}{*}{1} & Regression & & & & & \\
\hline & & 21.665 & 2 & 10.833 & 118.077 & $.000^{b}$ \\
\hline & Residual & 36.605 & 399 & .092 & & \\
\hline & Total & 58.271 & 401 & & & \\
\hline
\end{tabular}

a. Dependent Variable: Collective Leadership

b. Predictors: (Constant), sources of leadership efficacy, school culture 
INTERNATIONAL JOURNAL OF ACADEMIC RESEARCH IN BUSINESS AND SOCIAL SCIENCES

Vol. 8, No. 12, Dec, 2018, E-ISSN: 2222-6990 @ 2018 HRMARS

Coefficients $^{\mathrm{a}}$

\begin{tabular}{lllllll} 
& & \multicolumn{2}{l}{$\begin{array}{l}\text { Unstandardized } \\
\text { Coefficients }\end{array}$} & \multicolumn{3}{l}{$\begin{array}{l}\text { Standardized } \\
\text { Coefficients }\end{array}$} \\
\cline { 2 - 7 } Model & B & Std. Error & Beta & t & \multicolumn{1}{l}{ Sig } \\
\hline 1 & (Constant) & 1.672 & .143 & & 11.710 & .000 \\
\cline { 2 - 7 } & $\begin{array}{l}\text { Sources of } \\
\text { leadership } \\
\text { efficacy }\end{array}$ & .280 & .039 & .332 & 7.250 & .000 \\
$\begin{array}{l}\text { School } \\
\text { Culture }\end{array}$ & .307 & .038 & .372 & 8.134 & .000 \\
\hline
\end{tabular}

a. Dependent Variable: Collective Leadership

\section{Contribution of Sources of Leadership Efficacy Dimensions and School Culture Dimensions towards Collective Leadership}

A nine variable MLR model was proposed to explain the variation of collective leadership. The variables involved were Performance accomplishment $\left(X_{1}\right)$, Vicarious experience $\left(X_{2}\right)$, Social persuasion $\left(X_{3}\right)$, Emotional arousal $\left(X_{4}\right)$, Participative Leadership $\left(X_{5}\right)$,Teacher collaboration $\left(X_{6}\right)$, Professional development $\left(X_{7}\right)$ Unity of purpose $\left(X_{8}\right)$, Learning partnership $\left(X_{9}\right)$. The equation of proposed MLR model was a follows:

Equation 1: $Y(O C B)=b 0+b 1\left(X_{1}\right)+b 2\left(X_{2}\right)+b 3\left(X_{3}\right)+b 4\left(X_{4}\right)+b 5\left(X_{5}\right)+b 6\left(X_{6}\right)+b 7\left(X_{7}\right)+b 8\left(X_{8}\right)+b 9\left(X_{9}\right)+$ e

Table 3: Regression Analysis Based on Independent Variable Dimensions

\begin{tabular}{llllll}
\hline & $\boldsymbol{\beta}$ & SE & Beta & $\mathbf{t}$ & $\mathbf{p}$ \\
\hline Constant & 1.594 & .153 & & 10.413 & .000 \\
Performance accomplishment & .124 & .044 & .182 & 2.778 & .006 \\
Vicarious experience & .120 & .054 & .145 & 2.225 & .027 \\
Social persuasion & -.006 & .052 & -.009 & -.124 & .901 \\
Emotional arousal & .056 & .031 & .091 & 1.823 & .069 \\
Participative Leadership & .129 & .043 & .187 & 2.983 & .003 \\
Teacher collaboration & -.044 & .035 & -.075 & -1.252 & .211 \\
Professional development & .074 & .044 & .099 & 1.694 & .091 \\
Unity of purpose & .104 & .039 & .153 & 2.649 & .008 \\
Learning partnership & .048 & .032 & .076 & 1.494 & .136 \\
\hline
\end{tabular}

Notes: $R=0.620 \quad ; R^{2}=0.384 ;$ Adj. $R^{2}=0.370 \quad \mathrm{~F}=27.167 \quad ; \mathrm{p}=0.000$

From the regression analysis, it is was found that among all the variables, only four dimensions were significantly found to predict collective leadership since the $p$ value for those variables were less than $\alpha$ value 0.05 . Those variables are performance accomplishment, vicarious experience, participative leadership, and unity of purpose. Since all the four dimensions are positive, this indicates that there 
are positive relationships between the variables and outcome. Thus, when the collective leadership is exercised in school, it is justified that the most powerful of dimensions in sources of leadership efficacy, which is performance accomplishment, is exercised. Experiencing personal triumph, does have transforming effects on teachers. Vicarious experience, which simply means that good role models are pertinent, is further reinforced while participative leadership and unity of purpose serve to show that leadership roles out to be shared with a mission in frame.

If the effects of all the other variables were held constant, the $b$-value shows that participative leadership $(\beta=0.129, t(401)=2.983)$ makes the strongest contribution in explaining the collective leadership. It also can be seen that, if one unit increases in participative leadership it will contribute 0.129 unit for collective leadership. The R2 obtained was 0.384 which means the all the dimensions studied explained $38.4 \%$ of variance occur in collective leadership. The ANOVA result shows that $F$ value was large $(F=27.167, p<0.000)$. This shows that the slope for estimate linear regression line was not equal to zero. This confirmed that there was a linear relationship between the predictors and the dependent variables. If all the nine dimension of variables are taken as whole, only four variables were the most important determinants for collective leadership, while others do not influence collective leadership as significantly. However, when studied individually, each variable does significantly relate to collective leadership. Perhaps, future studies in other variables such as teacher commitment can be further explored to obtain similar kind of results as this research.

\section{Discussion}

Researchers in the field of education all across the globe would agree that leadership is one of the handful of issues demanding attention. This research is yet another manifestation of how leadership captured the researcher's attention. The point set out in this study is not just about the leadership concept but the investigation of leadership in teachers. In Malaysia, there is a dramatic transition, in symbiosis with the unprecedented change in culture and social change in the local community. Adopting collective leadership is an approach responding to these changes, enabling contributions through efforts as a team. This echoes findings from research done by $\mathrm{Ni}$ et. al. (2017) who say that improving collective leadership and maintaining the right balance of decision influence among stakeholders have the potential to create a harmonious and high-functioning school environment. Also, Friedrich et. al. (2009) have concluded that championing responsibilities is beneficial to team outcomes. This is the paradigm shift brought forth through collective leadership, which was confirmed through this study. Collective leadership is highly practiced by teachers involved in this study. Related literature highlights the coordinated and engaged efforts by administrators and teachers working and learning together as central to the culture of a winning school environment (Collinson \& Cook, 2007; Muijs \& Harris, 2003; Murphy, 2005 as cited in Browne-Ferrigno, 2016).

Key predictors to collective leadership in this study are sources of leadership efficacy and school culture, which implies that teachers are able to display a higher level of confidence in their leadership capability as they feel valued in their work and are professionally satisfied. This finding is further reciprocated by Walumba et.al. (2004) who found a positive effect of interaction between leadership and confidence, which can greatly contribute to employee productivity. This sentiment of interaction and confidence provides cohesion and convergence among teachers, the administration of the school 
and the students, which contribute to a positive school culture. Past studies have found positive and significant relationships between school culture and leadership practices (Turan \& Bektas, 2013; Ngang, 2012; Ali et. al., 2016; Mohd Yussoff, 2011).

Within sources of leadership efficacy, the most powerful dimensions turned out to be performance accomplishment and vicarious experience. Performance accomplishment is the belief that when tasks are easily mastered, it strengthens efficacy. This makes performance accomplishment the most crucial of source of leadership efficacy (Williams, 2015; Morris, 2010). In addition to being able to master tasks, a role model is equally central to boosting esteem. Also, research on effective schools enumerates the characteristics of exemplary schools, which serves to assist other organizations build themselves positively (Goddard, Hoy \& Hoy, 2000; Huh, Reigeluth \& Lee, 2014; Hannah et. al., 2008).

Lasting school improvement is achieved through school culture within which through this research the interplay between participative leadership and unity of purpose have been found to be dominant. This further reinforces the importance of collective leadership through collaboration and teamwork. A further powerful lever of focused goals can propel the belief in the generative power of collective leadership (Leithwood and Massey in Davies \& Brundrett, 2010). Therefore, leadership development should be key part of any comprehensive reform strategy, carefully aligned with elements of sources of leadership efficacy and school culture to realize its potential.

The school systems in Malaysia and globally are fast changing, propelling leaders to be alert to adjustments thrust upon them at micro and macro levels vis-à-vis, school and national context. This study is also hoped to cultivate awareness and intensify the involvement of principal and teachers in the management of the educational institution. The District Education Office, Department of Education, Institut Aminuddin Baki, Institute of Malaysian Teachers Education, National Institut of Public Administration (INTAN) and those assigned with developing leaders and leadership should take heed to provide awareness and knowledge of the importance to build teachers' esteem to school administrators and teachers alike.

\section{References}

Ali, N, Sharma, S. \& Zaman, A. (2016) School Culture \& School Effectiveness: Secondary Schools in Pakistan, Educational Management, 4 (4), 50-65

Avolio, B.J. \& Bass, B.M. (2004) Multifactor leadership questionnaire: manual and sampler set (3 ed.) Mind Garden Inc

Bandura, A. (1997) Self efficacy: The exercise of control, New York: Freeman

Battistich, V., Schaps, E., \& Wilson, N. (2004). Effects of an elementary school intervention on students' "connectedness" to school and social adjustment during middle school. Journal of Primary Prevention, 24(3), 243-262.

Bolman, L. \& Deal, T. (2013) Reframing Organizations: Artistry, choice and leadership (5 $5^{\text {th }}$ ed) New York, NY: John Wiley

Browne-Ferrigno, T (2016) Developing and Empowering Leaders for Collective School Leadership: Introduction to special issue, Journal of Research on Leadership Education, 11(2) 151-157 
INTERNATIONAL JOURNAL OF ACADEMIC RESEARCH IN BUSINESS AND SOCIAL SCIENCES

Vol. 8, No. 12, Dec, 2018, E-ISSN: 2222-6990 @ 2018 HRMARS

Chapman, C. \& Gregory, G. (2013). Differentiated instructional strategies: one size doesn't fit all (3rd Ed.). Thousand Oaks, CA: Sage Publications, Ltd./Corwin Press.

Chhabra, S. \& Yuvika. (2014). Gender and leadership: An analysis. ENVISION-Apeejay's Commerce \& Management Journal, 13, 112- 117.

Contractor, N. S., DeChurch, L. A., Carson, J. B., Carter, D. R., \& Keegan, B. (2012) The topology of collective leadership. Leadership Quarterly, 23, 994-1011

Cox, T. Jr (1993), Theory, Research and Practice: Cultural Diversity in Organizations, Berrett-Koehler, San Francisco, CA

Davies, B. \& Brundrett, M. (eds) (2010) Developing Successful Leadership, New York: Springer

Deal, T. E., \& Peterson, K. D. (1999). Shaping school culture: The heart of leadership. San Francisco: Jossey-Bass.

Friedrich, T. L., Griffith, J. A., \& Mumford, M. D. (2009) Collective leadership behaviors: Evaluating the leader, team network, and problem situation characteristics that influence their use. The Leadership Quarterly, 27(2), 312-333.

Fullan, M. (2001). Leading in the culture of change, San Fransisco: Jossey-Bass.

George, D. \& Mallery, M. (2003) SPSS for Window Step by Step: A simple guide and reference, 17.0 Update (10ed.) Boston: Pearson

Goddard, R. D., Hoy, W. K., \& Woolfolk Hoy, A. W. (2004). Collective efficacy beliefs: Theoretical developments, empirical evidence, and future directions. Educational Researcher, 33(3), 3-13.

Gruenert, S.W. \& Valentine, J.W. (1998) The school culture survey. Columbia, MO: University of Missouri-Columbia

Hannah, S.T., Avolio, B., Luthans, F. \& Harms, P.D. (2008) Leadership Efficacy: Review and Future Directions, Management Department Faculty Publications (5)

Hargreaves R.A., Halász, G. and Pont, B. (2007) School leadership for systemic improvement in Finland: A case study report for the OECD activity Improving school leadership viewed 28 July 2017 https://www.oecd.org/edu/school/39928629.pdf

House, P. W., \& Javidan, M. (2004). Culture, leadership, and organizations: The GLOBE study of 62 societies. London: Sage Publications

Huh, Y., Reigeluth, C.M. \& Lee. D. (2014) Collective Efficacy \& Its Relationship in a Computer-Mediated Project-Based Group Work, 5 (1), 1-21

Iyer, M.G. (2008) Current Views of the Characteristics of School Effectiveness in the context of National Secondary Schools From the Perception of Principals, Heads of Department and Teachers, Doctoral Thesis, University of Leicester, United Kingdom

Jamalulail, A.W., Aida Hanim, A.H., Suriati, Z \&Md Fuad, M.R. (2013) The relationship between head teacher's distributed leadership practices and teachers' motivation in national primary schools, Asian Social Science Journal $(9,16)$

Jayasingam, S \& Moey Y.C. (2009) Leadership Style and Perception of Effectiveness: Enlightening Malaysian Managers, Asian Social Science 5(2), 54-65

Jerald, C.D. (2006) Issue. Brief school culture: 'The Hidden Curriculum', Washington D.C.: The Center for Comprehensive School Reform and Improvement www.centerforcsri.org

Kirkpatick, S.A. \& Locke, E.A. (1991) Leadership: do traits matter? Academy of Management Executive, 5(2), 48-60 
INTERNATIONAL JOURNAL OF ACADEMIC RESEARCH IN BUSINESS AND SOCIAL SCIENCES

Vol. 8, No. 12, Dec, 2018, E-ISSN: 2222-6990 @ 2018 HRMARS

Lambert, L. (2003). A framework for shared leadership. Educational Leadership, 58(8), 37-40.

Leithwood, K. (2010). How the leading student achievement project improves student learning: An evolving theory of action. Retrieved on January, 21, 2012.

Leithwood, K., \& Louis, K. (2012). Linking leadership to student learning. San Francisco, CA: JosseyBass.

Leithwood, K. \& Mascall, B. (2008) Collective Leadership Effects on Student Achievement, Educational Administration Quarterly, 44 (4) 529-561

Leithwood, K. \& Jantzi, D. (2008) Linking leadership to student learning: The contributions of leader efficacy, Educational Administration Quarterly, 44 (4) 496-528

Louis, K.S., Marks, H.M. \& Kruse, S. (1996) Teachers' professional community in restructuring schools, American Educational Research Journal, 33, 757-798

Malaysia Education Blueprint (MEB) (2013) Malaysia Education Blueprint (2013-2025): preschool to post secondary education, Putrajaya: Ministry of Education

Maslowski, R. (2006) A review of inventories for diagnosing school culture, Journal of Educational Administration, 44(1), 6-35

McLeod, R.P. (2012). An examination of the relationships between teachers' sense of efficacy and school culture, Unpublished Doctorate Thesis, USA: University of Toledo

Mendez M. J. \& Busenbark J.R. (2015) Shared Leadership and gender: all members are equal but some more than others, Leadership \& Organisation Development Journal, 36 (1), 17-34

Milson, A.J. (2001) Teacher efficacy and character education. Paper presented at the Annual Meeting of the American Educational Research Association. (Seattle, WA, April 10-14, 2001)

Mohd. Yusoff, H. (2011) Budaya Organisasi Sekolah Menengah Harian: Satu Tinjauan di beberapa buah sekolah di Kuala Lumpur, University Malaya, KL

Moore, W. \& Esselman, M. (1992) Teacher efficacy, power, school climate and achievement. A desegregating district's experience. Paper presented at the Annual Meeting of the American Educational Research Association, San Fransisco: CA

Morris, D. (2010). Sources of teaching self efficacy: A scale validation (Unpublished Doctorate Thesis). Atlanta GA: Emory University

Ngang, T.K. (2012) A Comparative Study On Teacher Leadership In Special Education Classroom Between China and Malaysia, Procedia - Social \& Behavioral Sciences, 31, 231-235

Ni, Y.M., Rui Yan \& Pounder, D. (2017) Collective Leadership : Principals' Decision Influence and The Supportive or Inhibiting Decision Influence of Other Stakeholders, Educationa Administration Quarterly, 1-33

Pallant, J (2013) SPSS Survival Manual: A step by step guide to data analysis using IBM SPSS (5 ${ }^{\text {th }}$ ed.), UK: McGraw Hill

Pajares (2002) Self-efficacy beliefs in academic contexts: An outline. Retrieved from http://des.emory.edu/mfp/efftalk.html

Peterson, K., \& Deal, T. (2002). Shaping school culture fieldbook. San Francisco: Jossey-Bass

Pounder, D., Ogawa, R., \& Adams, E. (1995). Leadership as an organization-wide phenomena: Its impact on school performance. Educational Administration Quarterly, 31(4), 564-588. 
INTERNATIONAL JOURNAL OF ACADEMIC RESEARCH IN BUSINESS AND SOCIAL SCIENCES

Vol. 8, No. 12, Dec, 2018, E-ISSN: 2222-6990 @ 2018 HRMARS

Rabindarang, S., Khuan, W.B. \& Khoo, Y.Y. (2015) The influence of distributed leadership on job stress in technical and vocational education, International Journal of Academic Research in Business and Social Sciences, 4 (1), 490-499

Rahimah, H.A. \& Ghavifekr, S. (2014) School leadership for the $21^{\text {st }}$ century: A conceptual overview, Malaysian Online Journal of Educational Management, Vol.2: 1

Rosnazirah, A. H. \& Hussein, H. A. (2015) Distributed leadership, contextual factor and teachers' selfefficacy in Malaysia, Malaysian Online Journal of Educational Management, 3 (3), 1-12

Rosnazirah, A. H. \& Zulkifli, A.M. (2009) The prevalence of distributed leadership in selected secondary schools in Malaysia, paper presented at the $16^{\text {th }}$ National Seminar on Management and Leadership in Education, Aminuddin Baki Institute (IAB)

Ross, J.A. \& Gray, P. (2006) School leadership and student achievement: The mediating effects of teacher beliefs, Canadian Journal of Education 29, 3, 798-822

Sergiovanni, T. J. (2000). The lifeworld of leadership. San Francisco: Jossey-Bass.

Shaughnessy, M.F. (2004) An Interview With Anita Woolfolk: The Educational Psychology of Teacher Efficacy. Educational Psychology Review, 16 (2), 153-176

Sofi, S.N.S. \& Sharif, A.M.S. (2014) Transformational leadership of vocational college directors and self-efficacy of vocational college lecturers, Journal of Science, Mathematics and Technology $1(2), 30-40$

Tschannen-Moran, M., Woolfolk Hoy, A., \& Hoy, W. K. (1998). Teacher efficacy: Its meaning and measure. Review of Educational Research, 68, 202-248.

Turan, S., \& Bektas, F. (2013) The relationship between school culture and leadership practices. Eurasian Journal of Educational Research, 52, 155-168

Usher, E. L. (2006). Teaching self-efficacy, sources of teaching self-efficacy, teacher satisfication, teacher stress, collective teacher efficacy, optimism, teacher authenticity, and invitations. Unpublished raw data

Van Houtte, M. (2005) Climate or culture: A plea for conceptual clarity in

school effectiveness research. School Effectiveness and School Improvement, 16, 71-89

Walumbwa, F.O., Wang, P., Lawler, J.J., \& Shi, K. (2004). The role of collective efficacy in the relations between transformational leadership and work outcomes. Journal of Occupational and Organizational Psychology, 77, 515-530

Wepner, S. B., \& Hopkins, D. (2011). Collaborative leadership in action: Partnering for successes in schools. New York, NY: Teachers College Press.

Williams, K. M. (2015) Dynamics of Efficacy for Teachers in Formal Leadership Roles, Doctoral dissertation, East Tennessee State University.

Woolfolk Hoy, A., \& Davis, H.A. (2006). Teacher self-efficacy and its influence on the achievement of adolescents. In F. Pajares \& T. Urdan (Eds.), Self-efficacy of adolescents (pp. 117-137).

Greenwich, Connecticut: Information Age Publishing. 